\title{
Figures and Table
}

\section{Figures}

1.1 Organisation of British propaganda during the First World War 8

$\begin{array}{ll}1.2 & \text { Organisation of British propaganda, 1939-40 }\end{array}$
a. September-October 1939
b. October 1939-June 1940
c. June-July 1940

1.3 Organisation of British propaganda, 1940-1
a. July 1940-May 1941
b. May-September 1941

1.4 Organisation of British propaganda, 1941-5

a. September 1941-February 1942

b. February 1942-May 1945

2.1 White propaganda leaflets dropped over France, 1940-4 42

3.1 Courrier de l'Air, F.50/35 (1941) $\quad 75$

3.2 Courrier de l'Air, F.50/12 (1941) 79

3.3 'Why this photo concerns YOU', F.117 (1941) 84

3.4 'On the orders of Germany', F.107 (1941) 90

3.5 Courrier de l'Air, F.140 (1943) 98

3.6 'Proclamation', ZF.3 (1944) 102

5.1 'More than 1,000 bombers have bombed Cologne', FU. 57 (1942) 136

5.2 'Precautions against accidents', H.134B (1942) 139

\section{Table}

2.1 Target and actual dissemination, February and March 1944

\section{Copyright Acknowledgements}

Images in Figures 3.1-3.6, 5.1 and 5.2 are Crown Copyright and reproduced with the kind permission of the Controller of Her Majesty's Stationery Office. Figures 3.1, 3.3 and 3.4 are reproduced from the RAF Museum, Hendon. Figures 3.2, 3.5, 3.6, 5.1 and 5.2 are reproduced from the National Archives, Kew. All other figures, maps and tables used in this book were prepared by the author.

The BBC French Service scripts from which I quote are used with the kind permission of the BBC. 